\title{
Aspek Hukum Layanan Ojek Online Perspektif Undang-Undang Nomor 13 Tahun 2003 tentang Ketenagakerjaan
}

\author{
Sonhaji \\ Fakultas Hukum, Universitas Diponegoro \\ Email sonhajimuh19@gmail.com
}

\begin{abstract}
Online motorcycle now become an extraordinary phenomenon, especially for people in big cities who feel the impact of the existence of online motorcycle. The problem raised in this legal journal is about the implications of legal relations that arise between online motorcycle drivers and online motorcycle service providers from the perspective UU Number 13 of 2003 concerning Employment. The legal relationship arising from the agreement between the GOJEK driver and PT GO-JEK Indonesia as seen from its form is a partnership agreement. This partnership agreement is a partnership agreement that includes a new type of partnership agreement with profit sharing patterns as stipulated in Article 26 (letter f) UU Number 20 of 2008 concerning Micro, Small and Medium Enterprises. There is no work agreement that arises in the partnership relationship between PT GO-JEK and GO-JEK drivers because there is one element that is not fulfilled, namely the element of wages, thus the GO-JEK driver is not a worker because there is no working relationship between PT. JEK with GO-JEK drivers, there are only partnership relationships where both parties have the same position as partners. so that arrangements and problems relating to work protection cannot use UU Number 13 of 2003 concerning Employment.
\end{abstract}

Keywords. : Legal Relations, Ojek Driver, Ojek Online

\begin{abstract}
Abstrak
Ojek online kini telah menjadi sebuah fenomena luar biasa, terutama bagi masyarakat yang berada di kota-kota besar yang karena merasakan langsung dampak dari keberadaan ojek online tersebut. Permasalahan yang diangkat dalam jurnal hukum ini adalah mengenai implikasi dari hubungan hukum yang timbul antara pengemudi ojek online dengan penyedia layanan ojek online dari perspektif Undang-undang Nomor 13 Tahun 2003 tentang Ketenagakerjaan. Hubungan hukum yang timbul dari perjanjian antara pengemudi GO-JEK dengan PT GO-JEK Indonesia dilihat dari bentuknya merupakan perjanjian kemitraan. Perjanjian kemitraan ini merupakan perjanjian kemitraan yang termasuk perjanjian kemitraan jenis baru dengan pola bagi hasil sebagaimana diatur dalam Pasal 26(huruf f) Undang-undang Nomor 20 tahun 2008 tentang Usaha Mikro,Kecil,dan Menengah . Tidak ada perjanjian kerja yang timbul dalam hubungan kemitraan antra PT GO-JEK dengan driver GO-JEK dikarenakan ada salah satu unsur yang tidak terpenuhi yaitu unsur upah, dengan demikian driver GOJEK bukan merupakan pekerja karena tidak terjadinya hubungan kerja antara PT.GO-JEK dengan driver GO-JEK yang ada hanya hubungan kemitraan di mana kedua belah pihak memiliki kedudukan yang sama sebagai mitra. sehingga pengaturan dan masalah-
\end{abstract}


masalah yang berkaitan dengan perlindungan kerja tidak dapat menggunakan Undang-undang Nomor 13 tahun 2003 tentang Ketenagakerjaan

Kata Kunci. : Hubungan Hukum, Pengemudi Ojek, Ojek Online

\section{A. Pendahuluan}

Ojek online kini telah menjadi sebuah fenomena luar biasa, terutama bagi masyarakat yang berada di kota-kota besar yang karena merasakan langsung dampak dari keberadaan ojek online tersebut Pertumbuhan bisnis ojek berbasis online ini dalam perkembangannya diikuti dengan makin meningkatnya animo masyarakat. Hal ini ditandai denganjumlah pengunduh aplikasi GO-JEK ini sudah mencapai 10 (juta) juta orang pengunduh ${ }^{1}$. Kehadiran ojek online di Semarang tentunya menjadi angin segar bagi para masyarakat khususnya para pencari kerja. Semarang yang sejak dahulu terkenal sebagai kota atlas kini juga mengalami perkembangan sebagai provinsi yang memiliki kegiatan perekonomian yang terus berkembang dan arus perpindahan orang dan barang yang cepat dan terus meningkat, hal ini ditambah dengan tingkat kepadatan penduduk yang cukup besar. Maka tak heran jika sarana transportasi modern seperti ojek online ini sejak kemunculan pertamanya di Semarang kini sudah berkembang dengan pesat.

Terdapat fenomena menarik yang terjadi di masyarakat, masyarakat umum menganggap bahwa para penemudi ojek online merupakan karyawan dari perusahaan penyedia layanan aplikasi tersebut sehingga antara keduanya terdapat suatu hubungan kerja. Alasannya beragam mulai dari adanya kewajiban pengemudi ojek online menjaminkan surat berharga seperti ijazah atau surat-surat berharga lain saat awal mendaftar hingga masalah upah dan asuransi yang diberikan kepada para pengojek. Dalam prakteknya ternyata sistem rekrutmen mitra ojek online atau lazim disebut sebagai driver ojek online ini menggunakan sistem kemitraan.

Terdapat perbedaan antara perjanjian kerja dan perjanjian kemitraan namun demikian perlu untuk dilihat lebih lanjut praktik yang dilakukan karena perjanjian kemitraan yang dilakukan oleh penyedia layanan ojek online dengan driver ojek online terdapat adanya

\footnotetext{
${ }^{1}$ Google, GO-JEK, Playstore.com/apps/GO-JEK diakses pada tanggal 9Maret 2018, pukul 18.47 wib.
} 
kemiripan dengan perjanjian kerja. Perjanjian kerja dikatakan sebagai perjanjian antara pekerja/buruh dengan pengusaha atau pemberi kerja yang memuat syarat-syarat kerja, hak, dan kewajiban para pihak. Dalam hal ini perlu dilihat memang tidak semua unsur dalam perjanjian kemitraan sama dengan pernjanjian kerja. Beberapa hal dapat disamakan seperti dibuat oleh para pihak, kewajiban dan hak para pihak dan syarat-syarat kerja, walaupun untuk unsur pengupahan perlu dipastikan lebih lanjut. Upah adalah hak pekerja/buruh yang diterima dan dinyatakan dalam bentuk uang sebagai imbalan dari pengusaha atau pemberi kerja kepada pekerja/buruh yang ditetapkan dan dibayarkan menurut suatu perjanjian kerja, kesepakatan, atau peraturan perundangundangan, termasuk tunjangan bagi pekerja/buruh dan keluarganya atas suatu pekerjaan dan/atau jasa yang telah atau akan dilakukan.Praktik kemitraan yang dilaksanakan dengan hubungan yang cenderung subordinatif seperti pada perjanjian kerja walaupun secara yuridis harusnya koordinatif. Sebelum melakukan perjanjian kemitraan telah ditetapkan persyaratan secara sepihak oleh penyedia layanan ojek online atau dibuat dalam bentuk perjanjian standar yang klausul-klausulnya telah dibakukan dalam perjanjian.

Dalam bekerja driver sering berada di lokasi-lokasi yang daerah perkerjaannya rawan akan kecelakaan. Hal ini dapat menimbulkan akan adanya kecelakaan kerja yang diala mi oleh driver perihal pekerjaan ini dilakukan di jalur lalu lintas. Hal ini yang menjadi alasan mengapa perlunya perlindungan hukum terhadap Driver GOJEK yang mengalami kecelakaan pada saat bekerja. Perlindungan terhadap pekerja dalam hal ini driver, dimaksudkan untuk menjamin hak dasar pekerja dan menjamin kesamaan serta perlakuan tanpa diskriminasi atas dasar apapun untuk mewujudkan kesejahteraan pekerja dan keluarganya dengan tetap memperhatikan perkembangan kemajuan dunia usaha ${ }^{2}$.Beberapa hal di atas menjadi masalah yang perlu ditelaah dimulai dengan definisi hubungan hukum/perikatan yang terjadi antara penyedia layanan ojek online dan driver ojek online untuk lebih lanjut memastikan payung hukum yang dapat memberikan perlindungan optimal bagi kedua belah pihak terutama pengemudi ojek online.

\footnotetext{
${ }^{2}$ Wijayanti Asri, Hukum Ketenagakerjaan Pasca Reformasi, (Penerbit Sinar Grafika, Jakarta, 2009), hlm. 8.
} 
Berdasarkan uraian di atas, maka identifikasi dan rumusan pokok permasalahannya adalah sebagai berikut :

1. Bagaimana hubungan hukum yang timbul antara penyedia layanan ojek online dengan driver ojek online?

2. Bagaimana implikasi dari hubungan hukum yang timbul antara penyedia layanan ojek online dengan driver ojek online dari perspektif Undang-undang Nomor 13 Tahun 2003 tentang Ketenagakerjaan?

\section{Metode}

Penelitian ini menggunakan metode pendekatan yuridis empiris. Metode analisis hasil penelitianini menggunakan deskriptif analitis. Kegiatan ilmiahnya mencakup kegiatankegiatan : verifikasi, komparasi dengan berbagai narasumber dan informan penelitian yang terkait dengan topik penelitian.

\section{B. Pembahasan}

Menurut Soeroso, "hubungan hukum ialah hubungan antara dua atau lebih subjek hukum. Dalam hubungan hukum ini hak dan kewajiban pihak yang satu berhadapan dengan hak dan kewajiban pihak yang lain3". Hukum sebagai himpunan peraturan-peraturan yang mengatur hubungan sosial memberikan suatu hak kepada subjek hukum untuk berbuat sesuatu atau menuntut sesuatu yang diwajibkan oleh hak itu, dan terlaksananya kewenangan/hak dan kewajiban tersebut diijamin oleh hukum ${ }^{4}$.Setiap hubungan hukum mempunyai dua segi :segi bevoegdheid (kekuasaan / kewenangan atau hak) dengan lawanya plicht atau kewajiban. Kewenangan yang diberikan oleh hukum kepada subjek hukum (orang atau badan hukum) dinamakan hak. Mengenai hubungan hukum ini, Logemann sebagaimana dikutip oleh Soeroso berpendapat bahwa dalam tiap hubungan hukum terdapat pihak yang

\footnotetext{
${ }^{3}$ R. Soeroso.. Pengantar IImu Hukum. (Jakarta: Sinar Grafika. 2011)hlm $269{ }^{4}$ Ibid $\operatorname{hlm} 270$
} 
berwenang/berhak meminta prestasi yang disebut dengan prestatie subject dan pihak yang wajib melakukan prestasi disebut plicht subject. Hubungan hukum memiliki 3 unsur yaitu:

a. Adanya orang-orang yang hak/kewajiban saling berhadapan:

b. Adanya objek yang berlaku berdasarkan hak dan kewajiban

c. Adanya hubungan antara pemilik hak dan pengemban kewajiban atau adanya hubungan atas objek yang bersangkutan.

Syarat-syarat hubungan hukum adalah:

a. Adanya dasar hukum, ialah peraturan-peraturan hukum yang mengatur hubungan hukum itu, dan

b. Timbulnya peristiwa hukum.

Hubungan hukum yang timbul dari perjanjian antara pengemudi GO-JEK dengan PT GOJEK Indonesia dilihat dari bentuknya merupakan perjanjian kemitraan , yaitu bentuk umum suatu hubungan hukum antara satu pihak dengan pihak lainnya atas dasar hubungan kemitraan (partnership agreement). Ketentuan umum perjanjian kemitraan adalah Pasal 1338 jo Pasal 1320 Kitab Undang-Undang Hukum Perdata (KUH Perdata). Sedangkan, ketentuan khusus dalam Peraturan Pemerintah Nomor 44 tahun 1997 Tentang Kemitraan. Perjanjian kemitraan PT GO-JEK dengan driver ini merupakan perjanjian kemitraan yang termasuk perjanjian kemitraan jenis baru dengan pola bagi hasil sebagaimana diatur dalam Pasal 26(huruf f) Undang-Undang No. 20 Tahun 2008 Tentang Usaha Mikro,Kecil,dan Menengah dan diatur lebih lanjut dalam Peraturan Pemerintah nomor 17 tahun 2013 tentang pelaksanaan Undangundang Nomor 20 tahun 2008 tentang Usaha Mikro,Kecil,dan Menengah. Bentuk perjanjian tersebut merupakan bentuk perjanjian tertulis yang dituangkan dalam bentuk kontrak elektronik di mana diatur di dalam Undang-Undang No.11 Tahun 2008 Tentang Informasi dan Transaksi Elektronik tepatnya pada Pasal 18 Ayat

(1) yang berbunyi “ Transaksi elektronik yang dituangkan dalam kontrak elektronik mengikat para pihak ". 
Kerjasama kemitraan ini terdapat 4 pihak yang terkait yaitu, AKAB , PAB , DAB dan Mitra . AKAB , PAB , DAB ,dan Mitra merupakan mitra kerjasama di mana masing-masing merupakan subjek hukum yang berdiri sendiri dan independen. AKAB adalah pihak yang membuat, memiliki dan mengurus Aplikasi GO-JEK yang dimanfaatkan konsumen yang telah terdaftar untuk memperoleh jasa layanan antarjemput barang dan/atau orang, layanan pesan antar barang ataupun jasa lainnya dengan kendaraan bermotor roda dua maupun roda empat atau jasa lainnya, PAB atau PT Paket Anak Bangsa adalah sebuah perusahaan yang berafiliasi dang bekerjasama dengan AKAB yang melakukan kegiatan usaha penyelenggaraan pos, DAB atau PT Dompet Anak Bangsa adalah sebuah perusahaan yang berafiliasi dan bekerjasama dengan AKAB yang melakukan kegiatan usaha penyelenggaraan sistem uang elektronik dan Mitra adalah pihak yang melaksanakan antar-jemput barang dan / atau orang, pesan-antar barang yang sebelumnya telah dipesan konsumen, atau jasa lainnya melalui Aplikasi GO-JEK dengan menggunakan kendaraan bermotor roda dua yang dimiliki oleh Mitra sendiri. Perjanjian kerjasama ini tidak menciptakan hubungan ketenagakerjaan, outsourcing atau keagenan diantara masing-masing AKAB , PAB , DAB ,dan Mitra. ${ }^{4}$

Mitra memiliki kedudukan yang sama dalam teori kemitraan tidak seperti bawahan dengan atasan atau pekerja dengan pemberi kerja, Akan tetapi dalam prakteknya perjanjian antara pengemudi GO-JEK dengan PT GO-JEK terdapat beberapa perbedaan yaitu dalam penandatanganan perjanjian kemitraan, calon pegemudi GO-JEK diberikan kontrak yang sudah dibuat oleh PT GO-JEK atau sering disebut kontrak standar di mana calon pengemudi GO-JEK harus menaati isi kontrak yang telah ditetapkan tersebut tanpa dapat merubah atau merundingkan isi kontrak tersebut. Menurut isi Perjanjian kemitraan di atas AKAB mempunyai hak untuk memberlakukan syarat-syarat tambahan selain yang disebutkan di dalam perjanjian dan pengemudi GO-JEK harus menaati itu. Setiap syarat dan ketentuan yang diberlakukan oleh PAB maupun DAB sebagaimana dapat dirubah atau ditambahkan oleh PAB maupun DAB dari waktu ke waktu, sehubungan dengan penyelenggaraan jasa pos maupun

\footnotetext{
${ }^{4}$ Fajar Anggoro, wawancara . Driver GO-JEK , 23 Juli 2018
} 
penggunaan sistem uang elektronik. Beberapa hal di atas menunjukan adaya ketidak setaraan dalam perjanjian kemitraan ini .

\section{Hak dan Kewajiban Para Pihak}

Dalam hubungan hukum yang terjadi antara antara pengemudi GO-JEK dengan PT GOJEK Indonesia menimbulkan hak dan kewajiban bagi kedua belah pihak yaitu diantaranya driver berkewajiban menyetujui dan menaati semua persyaratan - persyaratan dan peraturan yang telah dibuat oleh PT GO-JEK diantaranya ${ }^{5}$ :

a. Driver wajib untuk mematuhi setiap peraturan lalu lintas, undang-undang dan peraturan hukum yang berlaku;

b. Driver wajib untuk mengenakan jaket dan helm GO-JEK yang dipinjamkan kepada driver oleh GI atas biaya yang dikenakan oleh GI yang akan diatur lebih lanjut melalui perjanjian terpisah. GI mempunyai hak untuk mengenakan kepada driver sanksi dalam jumlah yang dapat ditentukan oleh GI;

c. Driver wajib untuk menjaga kebersihan penampilan, berpakaian rapi, bersepatu, menggunakan seragam berupa jaket dan helm yang disediakan GI dan memelihara jaket dan helm yang disediakan GI;

d. Driver dilarang minum minuman keras, mabuk, madat, memakai narkotika ataupun berada dalam keadaan di mana driver tidak mempunyai kesadaran penuh;

e. Driver dilarang melakukan perbuatan asusila, penganiayan, penghinaan, penipuan atau pengancaman pihak ketiga baik Konsumen, driver lainnya ataupun pihak ketiga lainnya; f. Driver dilarang membujuk driver lain melakukan tindakan yang dapat diancam hukuman pidana;

g. Driver dilarang, baik dengan sengaja atau karena kelalaiannya, melakukan perbuatan atau membiarkan diri sendiri, Konsumen, dan/atau driver lainnya berada dalam keadaan yang dapat menimbulkan bahaya ke masing-masing pihak;

\footnotetext{
${ }^{5}$ Fajar Anggoro, wawancara . Driver GO-JEK , 23 Juli 2018
} 
h. Driver dilarang melakukan kegiatan, baik dengan sengaja atau karena kelalaiannya, yang dapat menghasilkan pencemaran nama baik GI ataupun AKAB maupun karyawan dan afiliasi dari GI dan AKAB;

i. Driver dilarang untuk menentukan harga untuk jasa yang diberikan kepada Konsumen melalui Aplikasi GO-JEK selain dari harga yang telah ditentukan dan disetujui oleh GI ataupun $\mathrm{AKAB}$;

j. Driver dilarang untuk membongkar atau menyebarluaskan informasi yang diberikan oleh GI ataupun AKAB, baik melalui Aplikasi GO-JEK maupun melalui cara lainnya, karyawan dari GI ataupun AKAB maupun afiliasi GI ataupun AKAB kepada driver tanpa persetujuan tertulis dari GI ataupun AKAB, sebagaimana berlaku;

k. Driver dilarang untuk meminta uang tambahan dalam bentuk apapun, termasuk namun tidak terbatas kepada dalam bentuk 'tips' kepada Konsumen selain dari harga maupun biaya jasa yang diberikan oleh driver yang akan ditentukan melalui Aplikasi GO-JEK;

1. Driver dilarang melakukan setiap tindakan yang dilarang oleh hukum ataupun dapat dianggap sebagai pelanggaran hukum yang berlaku.

m. Kewajiban pajak yang timbul kepada masing-masing Pihak berdasarkan peraturan perundang-undangan yang berlaku.

Driver memiliki hak-hak antara lain :

a. Berhak menggunakan aplikasi GO-JEK

b. Driver berhak menggunakan atribut-atribut GO-JEK diantaranya helm dan jaket GOJEK

c. Driver berhak memilih sendiri menerima pesanan dari pelanggan atau tidak sesuai dengan keinginan driver

d. Driver berhak atas bonus yang diberikan PT GO-JEK apabila mampu mencapai poin yang telah ditentukan PT GO-JEK.

Kewajiban dari PT GO-JEK sebagai penyedia layanan antara lain: a.

Mengatur segala urusan mengenai layanan-layanan GO-JEK

b. Melakukan pengawasan terhadap kinerja para driver 
c. Kewajiban pajak yang timbul kepada masing-masing Pihak berdasarkan peraturan perundang-undangan yang berlaku .

Hak dari PT GO-JEK antara lain:

a. Berhak menentukan persyaratan-persyaratan dan peraturan yang berlaku dalam perjanjian kemitraan dengan driver

b. Berhak mengubah atau menambah persyaratan dan peraturan yang telah dibuat sebelumnya

c. Barhak memperoleh bagi hasil dari driver

d. Berhak menegur atau bahkan menonaktifkan driver bila ada laporan tidak baik kepada driver

e. Berhak memperoleh pengembalian atribut dari driver apabila terjadi pemutusan perjanjian kemitraan, berhak melakukan promosi kepada konsumen

f. Serta berhak menentukan biaya yang harus dibayarkan oleh konsumen

\section{Implikasi Dari Hubungan Hukum Yang Timbul Antara Penyedia Layanan Ojek Online Dengan Driver Ojek Online Dari Perspektif Undang-Undang Nomor 13 Tahun 2003 Tentang Ketenagakerjaan}

Dalam UU No. 13 Tahun 2003 tentang Ketenagakerjaan, yang dimaksud dengan perjanjian kerja adalah perjanjian antara pekerja/ buruh dan pengusaha atau pemberi kerja yang memuat syarat-syarat kerja hak dan kewajiban kedua belah pihak. Sendjum W. Manulang berpendapat, ada beberapa unsur atau faktor yang menentukan adanya hubungan kerja yaitu: ${ }^{6}$

1. Adanya pekerjaan yang harus dilakukan

2. Adanya perintah

3. Adanya upah

${ }^{6}$ Sedjum W. Manalang Pokok-pokok Hukum Ketenagakerjaan Indonesia. (Rineka Cipta .Jakarta. 1990 ).hlm 64 
Tanpa adanya salah satu dari ketiga unsur tersebut maka tidak ada hubungan kerja. Sayangnya, bagian Penjelasan Undang-Undang Ketenagakerjaan tidak menjelaskan lebih jauh dan detil dari unsur-unsur hubungan kerja tersebut. Tidak adanya penjelasan lebih jauh mengenai unsurunsur hubungan kerja tersebut membuat setiap pihak memiliki penafsirannya masingmasing.Misalnya terlihat dalam kasus antara puluhan sopir dan sebuah perusahaan di bidang transportasi angkutan Pelabuhan Tanjung Perak Surabaya. Oleh karena peraturan di bidang ketenagakerjaan tidak menjelaskan lebih lanjut unsur hubungan kerja, maka penting untuk melihat bagaimana pandangan pengadilan terhadap ketiga unsur tersebut.

Putusan Mahkamah Agung Nomor 841 K/Pdt.Sus/2009 dalam perkara antara sopir taksi dan perusahaan taksi, dalam perkara itu Mahkamah Agung menyatakan tidak ada unsur upah karena para sopir taksi hanya menerima komisi/persentase. Selain itu, tidak ada unsur perintah karena sopir taksi diberi kebebasan mencari penumpangnya sendiri. Dari Putusan Mahkamah Agung di atas dapat ditarik kesimpulan mengenai unsur-unsur hubungan kerja sebagai berikut:

a. Pekerjaan: Unsur ini terpenuhi jika pekerja hanya melaksanakan pekerjaan yang sudah diberikan perusahaan.

b. Upah: Unsur ini terpenuhi jika pekerja menerima kompensasi berupa uang tertentu yang besar jumlahnya tetap dalam periode tertentu. Bukan berdasarkan komisi/persentase.

c. Perintah: Unsur ini terpenuhi jika pemberi perintah kerja adalah perusahaan. Bukan atas inisiatif pekerja.

Hubungan kemitraan yang terjadi antara PT GO-JEK dengan driver GO-JEK untuk dapat terjadi hubungan kerja maka harus terpenuhi ketiga unsur di atas.

1. Unsur yang pertama adanya pekerjaan yang harus dilakukan

Dalam pekerjaannya driver GO-JEK mendapat pekerjaan yang berasal dari PT.GO-JEK melalui aplikasi GO-JEK di mana konsumen memesan jasa driver GO-JEK untuk antarjemput barang dan/atau orang, layanan pesan-antar barang dengan kendaraan bermotor roda dua maupun roda empat atau jasa lainnya yang terkait.

2. Unsur yang kedua adalah perintah 
Driver GO-JEK mendapat perintah dari PT. GO-JEK di mana konsumen memesan jasa melalui aplikasi GO-JEK, akan tetapi menurut beberapa narasumber yang berprofesi sebagai driver GO-JEK, menjelaskan bahwa mereka memiliki hak untuk memilih apakah akan menerima pekerjaan itu atau tidak, dengan kata lain driver GO-JEK diberi kebabasan memilih pekerjaan yang akan diambilnya.

3. Unsur yang ketiga yaitu upah

Pengertian upah dalam Undang-undang Nomor 13 Tahun 2003 tentang Ketenagakerjaan Pasal 1 Angka 13

"Upah adalah hak pekerja/buruh yang diterima dan dinyatakan dalam bentuk uang sebagai imbalan dari pengusaha atau pemberi kerja kepada pekerja/buruh yang ditetapkan dan dibayarkan menurut suatu perjanjian kerja, kesepakatan, atau peraturan perundangundangan, termasuk tunjangan bagi pekerja/buruh dan keluarganya atas suatu pekerjaan dan/atau jasa yang telah atau akan dilakukan."

Dalam perjanjian kemitraan antara PT.GO-JEK dengan driver GO-JEK menggunakan sistim bagi hasil, ini menandakan PT.GO-JEK tidak membayar upah secara langsung kepada driver GO-JEK , driver mendapat upah langsung dari konsumen pada saat memberikan jasanya , terlebih lagi driver justru harus membagi hasil tersebut untuk disetorkan kepada PT. GO-JEK sesuai dengan isi perjanjian kemitraan tersebut.Akan tetapi dalam kerjasama ini driver GOJEK diberi bonus tambahan oleh PT GO-JEK apabila memperoleh capaian tertentu, sistem bonus itu didapatkan oleh driver setiap hari jika memenuhi target poin yang telah ditentukan oleh PT GOJEK. ${ }^{7}$ Target poin yang harus dipenuhi dan nominal yang akan didapatkan adalah sebagai berikut:

1. 14 poin $=\operatorname{Rp} 15.000$

2. 16 poin $=\operatorname{Rp} 25.000$

3. 20 poin $=\operatorname{Rp} 40.000$

1 hari yang sama menyelesaikan order ( total 20 poin ) maksimal bonus yang diterima adalah Rp 80.000 . Penghitungan poin dalam 1x order mendapat 1-3 poin ,tergantung dari syarat-

\footnotetext{
${ }^{7}$ Fajar Anggoro, wawancara . Driver GO-JEK , 23 Juli 2018
} 
syarat poin yang telah ditetapkan oleh PT.GO-JEK. Pengertian bonus menurut KBBI ( Kamus Besar Bahasa Indonesia ) Bonus memiliki arti "upah tambahan di luar gaji atau upan sebagai hadiah atau perangsang“, sedangkan pengertian upah dalam KBBI adalah " uang atau sebagainya yang dibayarkan sebagai pembalas jasa atau sebagai pembayar tenaga yang sudah dikeluarkan untuk mengerjakan sesuatu“. Dari kedua pengertian tersebut dapat ditarik kesimpulan bahwa bonus tidak dapat disamakan dengan upah sehingga unsur ketiga yakni upah tidaklah terpenuhi.

Tidak adanya perjanjian kerja yang timbul dalam hubungan kemitraan antra PT GO-JEK dengan driver GO-JEK dikarenakan ada salah satu unsur yang tidak terpenuhi yaitu unsur upah .Di mana PT.GOJEK tidak memberi upah kepada driver GO-JEK justru driver harus menyetorkan sebagian hasil dari pekerjaanya. Walau pun ada bonus harian yang diberikan kepada driver bila memenuhi capaian tertentu,akan tetapi ini tidak bisa disebut sebagai upah . Dengan demikian driver GO-JEK bukan merupakan pekerja karena tidak terjadinya hubungan kerja antara PT.GO-JEK dengan driver GO-JEK, yang ada hanya hubungan kemitraan di mana kedua belah pihak memiliki kedudukan yang sama sebagai mitra. sehingga pengaturan dan masalah-masalah yang berkaitan dengan perlindungan kerja tidak dapat menggunakan Undang-undang Nomor 13 tahun 2003 tentang Ketenagakerjaan. Kedua belah pihak apabila terjadi sengketa maka penyelesaiannya bukan menjadi wewenang pengadilan industrial tetapi menjadi wewenang pengadilan Negeri atau pengadilan umum baik di bidang perdata maupun pidana sesuai dengan kesepakatan yang telah di setujui oleh kedua belah pihak.

\section{Kesimpulan}

Hubungan hukum yang timbul dari perjanjian antara pengemudi GO-JEK dengan PT GO-JEK Indonesia dilihat dari bentuknya merupakan perjanjian kemitraan, yaitu bentuk umum suatu hubungan hukum antara satu pihak dengan pihak lainnya atas dasar hubungan kemitraan (partnership agreement). Ketentuan umum perjanjian kemitraan adalah Pasal 1338 jo Pasal 1320 Kitab Undang-

Undang Hukum Perdata ("KUH Perdata"). Sedangkan, ketentuan khusus dalam Peraturan Pemerintah Nomor 44 Tahun 1997 Tentang Kemitraan. Perjanjian kemitraan PT GO-JEK 
dengan driver ini merupakan perjanjian kemitraan yang termasuk perjanjian kemitraan jenis baru dengan pola bagi hasil sebagaimana diatur dalam Pasal 26(huruf f) UndangUndang No. 20 Tahun 2008 Tentang Usaha Mikro,Kecil,dan Menengah dan diatur lebih lanjut dalam Peraturan Pemerintah nomor 17 tahun 2013 tentang pelaksanaan Undangundang Nomor 20 tahun 2008 tentang Usaha Mikro,Kecil,dan Menengah . Bentuk perjanjian tersebut merupakan bentuk perjanjian tertulis yang dituangkan dalam bentuk kontrak elektronik di mana diatur di dalam Undang-Undang No.11 Tahun 2008 Tentang Informasi dan Transaksi Elektronik tepatnya pada Pasal 18 Ayat (1) yang berbunyi

" Transaksi elektronik yang dituangkan dalam kontrak elektronik mengikat para pihak ".

Implikasi dari hubungan hukum yang timbul antara penyedia layanan ojek online dengan driver ojek online Dari Perspektif Undang-Undang Nomor 13 Tahun 2003 Tentang Ketenagakerjaan. Tidak ada perjanjian kerja yang timbul dalam hubungan kemitraan antra PT GO-JEK dengan driver GO-JEK dikarenakan ada salah satu unsur yang tidak terpenuhi yaitu unsur upah .Di mana PT.GOJEK tidak memberi upah kepada driver GO-JEK justru driver harus menyetorkan sebagian hasil dari pekerjaanya. Walaupun ada bonus harian yang diberikan kepada driver bila memenuhi capaian tertentu,akan tetapi ini tidak bisa disebut sebagai upah . dengan demikian driver GO-JEK bukan merupakan pekerja karena tidak terjadinya hubungan kerja antara PT.GO-JEK dengan driver GO-JEK yang ada hanya hubungan kemitraan di mana kedua belah pihak memiliki kedudukan yang sama sebagai mitra. sehingga pengaturan dan masalah-masalah yang berkaitan dengan perlindungan kerja tidak dapat menggunakan Undang-undang Nomor 13 tahun 2003 tentang Ketenagakerjaan. Apabila terjadi sengketa antara kedua belah pihak maka penyelesaianya bukan menjadi wewenang pengadilan industrial tetapi menjadi wewenang pengadilan Negeri atau pengadilan umum baik di bidang perdata maupun pidana .

Adapun saran- saran yang dapat disampaikan dalam penulisan hukum ini adalah Berkaitan dengan Perjanjian Kerjasama Kemitraan terkait hubungan hukum antara PT. GOJEK dengan driver seharusnya diberikan pembaharuan Perjanjian yang baru. Di mana dalam perjanjian tersebut jelas tertulis mengenai hak dan kewajiban masing-masing pihak dan pembaharuan mengenai hubungan kerja agar sesuai dengan Undang-Undang 
Ketenagakerjaan. Perlunya peran pemerintah dalam melindungi hak-hak driver GO-JEK.di mana driver GO-JEK sebagai pihak yang lemah dalam perjanjian kemitraan ini.Seperti jaminan kesehatan harus diberikan apabila driver GO-JEK bersangkutan sakit karena bekerja di luar ruangan. Serta memiliki asuransi kecelakaan kepada tiap-tiap driver GOJEK karena lingkup pekerjaan mereka berada dilalu lintas perjalanan.

\section{Daftar Pustaka}

Abdulkadir. 1982. Hukum Perikatan. Alumni; Bandung, Agusmidah dkk. 2012 . Bab-Bab Tentang Hukum Perburuhan Indonesia-Ed.1. Denpasar: Pustaka Larasan; Jakarta: Universitas Indonesia; Universitas Leiden, Universitas Groningen,

Arikuntoro, Suharsimi. 2002. Prosedur Penelitian: Suatu Pendekatan Asri, Wijayanti. 2009, Hukum Ketenagakerjaan Pasca Reformasi, Penerbit Sinar Grafika, Jakarta

Bakri ,Muhammad.1995.Pengantar Hukum Indonesia. Penerbit IKIP Malang. Malang. Budi, Seta September 2016, "Peranan System Informasi Manajemen Pada Go.Jek", Penulisan Jurnal Ilmiah, Vol.3 No.1

Djumadi.2004.Tentang Ketenagakerjaan.Jakarta

Djumialdji. 1992. Hukum Perburuhan Perjanjian Kerja . Rajawali. Jakarta.

Faulidi Asnawi,Haris. 2004. Transaksi Bisnis E-Commerce Perspektif Islam. Magistra Insania Press. Yogyakarta

Husni . Lalu. 2015.Pengantar Hukum Ketenagakerjaan,Edisi Revisi . Rajawali Pers. Jakarta .

Ibrahim, Johnny .Teori \& Metodologi Penelitian Hukum Normatif. 2011. Bayumedia Publishing; Malang

Jafar Hafsah, Muhammad. 1999. Kemitraan Usaha. Pustaka Sinar Harapan; Jakarta

Kitab Undang-Undang Hukum Perdata

Manulang, Sedjum W. 1990 . Pokok-Pokok Hukum Ketenagakerjaan Indonesia. Rineka Cipta .Jakarta.

Martokusumo, Sudikno. 1986 .Mengenal Hukum. Liberty; Yogyakarta

Muhammad, Abdulkadir. 2000. Hukum Perdata Indonesi. PT. Citra Aditya Bakti, Bandung,hlm

Nur damayanti, Mia . 2009. Kajian Pelaksanaan Kemitraan Dalam Menigkatkan Pendapatan Antara Petani Semangka di Kabupaten Kebumen Jawa Tengah dengan CV. Bimandiri. IPB Press; Bogor

Pendidikan Nasional, Departemen .1989. Kamus Besar Bahasa Indonesia. Balai Pustaka; Jakarta

Pengangkutan di Indonesi. Rineka Cipta. Jakarta 
Peraturan Pemerintah Nomor 17 Tahun 2013 Tentang Pelaksanaan Undang-Undang Nomor 20 Tahun 2008 tentang Usaha Mikro, Kecil, dan Menengah Peraturan Pemerintah Nomor 44 Tahun 1997 Tentang Kemitraan

Praktek. Rianeka Cipta; Jakarta

Salim, Peter dan Salim, Yenny. 1991. Kamus Bahasa Indonesia. Edisi I. Jakarta

Satrio.1992.Hukum Perjanjian.Penerbit,PT. Citra Aditia Bakti;Bandung,

Soekanto , Soerjono dan .Mamudji, Sri. 2012 . Penelitian Hukum Normatif: Suatu

Tinjauan Singkat. Rajawali Pers;Jakarta

Soekanto ,Soerjono. 1986. Pengantar Penelitian Hukum. UI-Press; Jakarta

Soepomo ,Iman. 1987. Pengantar Hukum Perburuha., Penerbit Djambatan.Jakarta

Soepomo, Iman.2001.Hukum Perburuhan Bidang Hubungan Industrial. Pradaya

Paramita. Bandung

Subekti,R. 2009. Hukum Perjanjian .PT Intermasa ; Jakarta

Sugiyono.2009.Metode Penelitian Kuantitatif Kualitati. Alfabeta ; Jakarta .

Teguh Sulistiyani,Ambar. 2004. Kemitraan dan Model-Model Pemberdayaan . Gaya

Media.Yogyakarta.

Undang-Undang Nomor 13 Tahun 2013 tentang Ketenagakerjaan

Undang-Undang Nomor 11 Tahun 2008 Tentang Informasi Transaksi Elektronik

Undang-Undang Nomor 20 Tahun 2008 tentang Usaha Mikro, Kecil, dan Menengah

Undang-Undang Nomor 22 Tahun 2009 Tentang Lalu Lintas Jalan dan Angkutan Jalan

Usman Adji, Sution . Prakoso ,Djoko dan Pramono, Hari .1991. Hukum

Wibisono, Yusuf. 2007. Membedah Konsep dan Aplikasi CSR. Fascho Publishing; Gresik. 